\title{
A Review of Effect on Compressive Strength of Concrete After Addition of Nano-Silica
}

\author{
Renu Tiwar ${ }^{1}$, Neha Gupta ${ }^{2}$ \\ ${ }^{1}$ Department of Civil, Dr. C.V. Raman University, Bilaspur (C.G.) \\ ${ }^{2}$ Department of Civil, RKDF College of Engineering, Bhopal (M.P.)
}

\begin{abstract}
The research mainly focusing on the use of nanomaterials in concrete. Further researchers are continuing to improve the durability and sustainability of concrete and have realized significant increment in mechanical properties of concrete by incorporating nano-silica. The review paper summarizes the effect of nano-silica addition compressive strength on concrete. It provides the current development of application of nano-silica in paste, mortar and concrete. Finally, the future trend/potential and implication of nanosilica in cement-based materials is discussed.

A great number of researches have been performed to understand the nature of nanomaterials and their effect on the properties of concrete. A number of Research \& Development work dealing with the use of nanomaterials like Nano silica, colloidal Nano Silica $(\mathrm{CNS}), \mathrm{AlO}_{3}, \mathrm{TiO}^{2}, \quad \mathrm{ZrO}_{2}, \mathrm{Fe}_{2} \mathrm{O}_{3}$, carbon nanotubes $(C N T)$ in cement based materials are discussed in the literature.
\end{abstract}

Key words: Concrete, Nano silica, Compressive strength.

\section{Introduction}

Concrete is the material of present as well as future. There are the wide use of it in structures, from buildings to factories, from bridges to airports, makes it one of the most investigated materials of the $21^{\text {st }}$ century. Due to the rapid population explosion and the technology boom to cater to these needs, there is an urgent need to improve the strength and durability of concrete. Out of the various materials used in the production of concrete, cement plays a major role due its size and adhesive property. So, to produce concrete with improved properties, the mechanism of cement hydration has to be studied properly and better substitutes to it have to be suggested. Different materials known as supplementary cementitious materials or SCMs are added to concrete improve its properties. Some of these are fly ash, blast furnace slag, rice husk, silica fumes and even bacteria. Of the various technologies in use, nano-technology looks to be a promising approach in improving the properties of concrete.

\section{Nanomaterials- Use in Concrete}

Nano-materials are very small sized materials with particle size in nanometres. These materials are very effective in changing the properties of concrete at the ultrafine level by the virtue of their very small size. The small size of the particles also means a greater surface area (Alireza Naji Givi, 2010). Since the rate of a pozzolanic reaction is proportional to the surface area available, a faster reaction can be achieved. Only a small percentage of cement can be replaced to achieve the desired results. These nanomaterials improve the strength and permeability of concrete by filling up the minute voids and pores in the microstructure.

The use of nanosilica in concrete mix has shown results of increase in the compressive, tensile and flexural strength of concrete. It sets early and hence generally requires admixtures during mix design. Nanosilica mixed cement can generate nano-crystals of C-S-H gel after hydration. These nano-crystals accommodate in the micro pores of the cement concrete, hence improving the permeability and strength of concrete.

\section{Literature Review}

G. Dhinakaran et. al. (2014) analysed the microstructure and strength properties of concrete with Nano $\mathrm{SiO}$. The silica was ground in the planetary ball mill till nano size reached and it was blended in concrete with 5\%,10\% and 15\% b.w.c..The experimental results showed gain in compressive strength with maximum strength for $10 \%$ replacement.

Mukharjee and Barai (2014) the compressive strength and charcteristics of Interfacial Transition Zone (ITZ) of concrete containing recycled aggregates and nano-silica. An improvement in the compressive strength and microstructure of concrete was observed with the incorporation of nano silica.

Min. Hong Zhang et.al. (2012) studied the effect of NS \& high volume slag mortar on setting time and early strength and observed that rate of hydration increases with addition of NS, compressive strength of slag mortar increases with increase in NS dosages from 0.5 to $2 \%$ by weight of cement. $2 \%$ NS reduces initial and final setting time and compressive strength increases by $22 \%$ and $18 \%$ at 3 days and 7 days 
with addition of 50\% slag. NS with particle size $7 \& 12 \mathrm{~nm}$ are more effective in increasing cement hydration and reaction compared with silica fume.

J.Comiletti et.al. (2012) investigated the effect of micro and nano $\mathrm{CaCO} 3$ on the early age properties of ultra-high performance concrete (UHPC) cured in cold and normal field conditions.

The micro $\mathrm{CaCO} 3$ was added from 0 to $15 \%$ b.w.c. and nano $\mathrm{CaCO} 3$ was added at the rate of $0,2.5$ and 5\% b.w.c. Results show that by incorporating nano and micro $\mathrm{CaCO} 3$ the flow ability of 10UHPC is higher than the control mix which increases the cement replacement level. The mixture containing 5\% nano $\mathrm{CaCO} 3$ and $15 \%$ micro $\mathrm{CaCO} 3$ gives shortest setting time at $10{ }^{\circ} \mathrm{C}$ and at $20^{\circ} \mathrm{C}$ the highest $24 \mathrm{hrs}$ compressive strength is achieved by replacing cement with $2.5 \%$ nano and $5 \%$ micro $\mathrm{CaCO} 3$ and highest compressive strength at 26 days was achieved at $0 \%$ nano and $2.5 \%$ micro $\mathrm{CaCO} 3$.

Heidari and Tavakoli (2012) investigated the combined effect of replacement of cement byground ceramic powder from $10 \%$ to $40 \%$ b.w.c. and nano $\mathrm{SiO} 2$ from 0.5 to $1 \%$. A substantial decrease in water absorption capacity and increase in compressive strength was observed when $20 \%$ replacement is done with ground ceramic powder with 0.5 to $1 \%$ as the optimum dose of Nano $\mathrm{SiO} 2$ particles.

Surya Abdul Rashid et.al. (2011) worked on the effect of Nano $\mathrm{SiO} 2$ particle on both mechanical properties (compressive, split tensile and flexural strength) and physical properties (water permeability, workability and setting time) of concrete which shows that binary blended concrete with nano $\mathrm{SiO} 2$ particles up to $2 \%$ has significantly higher compressive, split tensile and flexural strength compared to normal concrete. Another inference drawn was that partial replacement of nano $\mathrm{SiO} 2$ particles decreases the workability and setting time of fresh concrete for samples cured in lime solution.

Ali Nazari et.al. (2011) studied strength and percentage water absorption of SCC containing different amount of GGBFS and TiO2 nano particles. The findings of the experimentation are that replacement of Portland cement with up to $45 \%$ weight of GGBSF and up to $4 \%$ weight of $\mathrm{TiO} 2$ nano particles gives a considerable increase to the compressive, split tensile and flexural strength of the blended concrete. This increase is due to more the formation of hydrated products in presence of $\mathrm{TiO} 2$; also the water permeability resistance of hardened concrete was improved. The author also studied effect of $\mathrm{CuO}$ nano particles on SCC and observed that increased percentage of polycarboxylate admixture content results in decreased compression strength. The $\mathrm{CuO}$ nano particles of average particle size $15 \mathrm{~nm}$ content with up to $4 \%$ weight increased the compressive strength of SCC. $\mathrm{CuO}$ nano particles up to $4 \%$ could accelerate the first peak in conduction calorimetric testing which is related to the acceleration of formation of hydrated cement products.

Sekari and Razzaghi (2011) study the effect of constant content of $\mathrm{Nano}_{\mathrm{ZrO}}, \mathrm{Fe}_{2} \mathrm{O}_{3}, \mathrm{TiO}_{2}$, and $\mathrm{Al}_{2} \mathrm{O}_{3}$ on the properties of concrete. The results showed that all the nano particles have 9 noticeable influence on improvement on durability properties of concrete but the contribution of nano $\mathrm{Al}_{2} \mathrm{O}_{3}$ on improvement of mechanical properties of HPC is more than the other nano particles.

M.S. Morsy et. al. (2010) studied the effect of nano-clay on the mechanical properties and microstructure of Portland cement mortar and observed that the tensile and compressive strength increased by $49 \%$ and $7 \%$ respectively at $8 \%$ nano-metakaolin (NMK).

Surya Abdul Rashid et.al. (2011) worked on the effect of Nano SiO2 particle on both mechanical properties (compressive, split tensile and flexural strength) and physical properties (water permeability, workability and setting time) of concrete which shows that binary blended concrete with nano $\mathrm{SiO}_{2}$ particles up to $2 \%$ has significantly higher compressive, split tensile and flexural strength compared to normal concrete. Another inference drawn was that partial replacement of nano $\mathrm{SiO}_{2}$ particles decreases the workability and setting time of fresh concrete for samples cured in lime solution.

Ali Nazari et.al. (2011) studied strength and percentage water absorption of SCC containing different amount of GGBFS and $\mathrm{TiO}_{2}$ nano particles. The findings of the experimentation are that replacement of Portland cement with up to $45 \%$ weight of GGBSF and up to $4 \%$ weight of $\mathrm{TiO}_{2}$ nano particles gives a considerable increase to the compressive, split tensile and flexural strength of the blended concrete. This increase is due to more the formation of hydrated products in presence of $\mathrm{TiO} 2$; also the water permeability resistance of hardened concrete was improved. The author also studied effect of $\mathrm{CuO}$ nano particles on SCC and observed that increased percentage of polycarboxylate admixture content results in decreased compression strength. The $\mathrm{CuO}$ nano particles of average particle size $15 \mathrm{~nm}$ content with up to $4 \%$ weight increased the compressive strength of SCC. $\mathrm{CuO}$ nano particles up to $4 \%$ could accelerate the first peak in conduction calorimetric testing which is related to the acceleration of formation of hydrated cement products.

Ali Nazari et.al. (2010) studied the combined effect of Nano SiO2 particles and GGBFS on properties of concrete. They used nanosilica with $3 \%$ b.w.c. replacement and $45 \%$ b.w.c. GGBFS, which shows improved split tensile strength. An improvement in the pore structure of SCC with silica particles was observed. Apart from this hey have studied the effect of $\mathrm{ZnO} 2$ nano particles on SCC concrete with constant w/c ratio of 
0.4. The results showed that by increasing the content of super plasticizer flexural strength decreases. Upto $4 \%$ b.w.c. of $\mathrm{ZnO} 2$ content an increase in the flexural strength of SCC was recorded. In another experiment the same author studied effect of $\mathrm{Al}_{2} \mathrm{O}_{3}$ nano particles on the properties of concrete. The results showed that cement could be replaced up to $2 \%$ for improving mechanical properties of concrete, but $\mathrm{Al}_{2} \mathrm{O}_{3}$ nano particles decreased percentage water absorption of concrete. XRD analysis of the sample showed that there is more rapid formation of hydrated product.

M. Collepardi et.al. (2010) studied the effect of combination of silica fume, fly ash and ultrafine amorphous colloidal silica (UFACS) on concrete. The result shows that steam cured concrete containing SF and FA alone are much stronger than NC cured at room temperature at early age where as compressive strength at 28-90 days of steam cured concrete is less than NC curedat room temperature. So author advised to use SF, FA\&UFACS for the manufacturing of precast unit.

\section{Conclusion}

The present paper reviews the current state of the field of nanotechnology in concrete and recent key advances. Current status of nano-silica opens up widely for research in cementitious compositions. Applications of nanotechnology have the potential to make breakthrough in materials technology. Nanosilica application in paste, mortar and concrete is a good way of enhancing their properties. It has been observed that optimum quantity of nano-silica to be used is still contradictory and it is for the researcher to decide the optimum quantity for his/her own material. Using nanotechnology in future will make it possible to design materials for their specific purpose of application. New developments have taken place in the nano-engineering and nano modification of concrete; however, current challenges need to be solved before the full potential of nanotechnology can be realized in concrete applications, including proper dispersion, compatibility of the nanomaterials in cement.

Additionally, introduction of these novel materials into the public sphere through civil infrastructure will necessitate an evaluation and understanding of the impact they may have on the environment and human health.

\section{References}

[1]. Ali Nazari, Shadi Riahi, Shirin Riahi, Saydeh Fatemeh Shamekhi and A. Khademno.. Embedded ZrO2 nanoparticles mechanical properties monitoring in cementitious composites. Journal of American Science 6(4), 2010, 86-89.

[2]. Ali Nazari, Shadi Riahi, Shirin Riahi, Saydeh Fatemeh Shamekhi and A. Khademno. Improvement of the mechanical properties of the cementitious composites byusing TiO2 nanoparticles. Journal of American Science 6(4), 2010, 98-101.

[3]. Ali Nazari, Shadi Riahi, Shirin Riahi, Saydeh Fatemeh Shamekhi and A. KhademnoMechanical properties of cement mortar with Al2O3 nanoparticles. Journal of American Science 6(4), 2010, 94-97.

[4]. Alireza Naji Givi, Suraya Abdul Rashid, Farah Nora A. Aziz and Mohamad Amra Mohd Salleh Experimental investigation of the size effects of $\mathrm{SiO} 2$ nano particles on the mechanical properties of binary blended concrete. Composites: Part B 41, 2010.673-677.

[5]. G.Quercia and H.J.H.Brouwers, Application of nanosilica(nS) in concrete mixtures. 8th fib PhD symposium in Kgs. Lyngby, Denmark. (2010).

[6]. M.S. Morsy, S.H. Alsayed and M. Aqel. Effect of Nano clay on mechanical properties and microstructure of Ordinary Portland Cement mortar. International Journal on Civil Engineering \& Environmental Engineeering IJCEE-IJENS Vol. 10 No. 01. 2010, 43

[7]. Shekari, A. H. and Razzaghi, M. Influence of nanoparticles on durability and mechanical properties of SCC with GGBFS as binder. Energy and buildings Vol. 43, 2011,995-1002.

[8]. Givi, A. N. and Rashid, S. A. The effect of lime solution on the properties of $\mathrm{SiO} 2$ nanoparticles binary blended concrete. Composites (Part B) Vol. 42, 2011,562-569.

[9]. Chahal, Navneet and Rafat Siddique. Influence of bacteria on thecompressivestrength, water absorption and rapid chloride permeabilty of concrete incorporating siloca fume. Construction and Building Materials 37, 2012, 645-651.

[10]. A.M. Said, M.S. Zeidan, M.T. Bassuomi and Y. Tian.. Properties of concrete incorporating nano-silica. Construction and Building Materials 36, 2012, 838-844.

[11]. Heidari, A., and Tavakoli, D. A study of mechanical properties on ground ceramic powder concrete incorporating nano $\mathrm{SiO} 2$ particles. Construction and Building Materials Vol. 38,

[12]. 2012, 255-264.

[13]. Navneet Chahal and Rafat Siddique. Permeation properties of concrete made with fly ash and silica fume: Influence of ureolytic bacteria. Construction and Building Materials 49,

[14]. 2013,161-174.

[15]. Shakir A. Al-Mishhamid, Amer M.Ibraham and Zeinab H. Naji. The effect of nano metakaolin materials on some properties of concrete. Diyala Journal of Enginnering Sciences, Vol. 06, No. 01, 2013, 50-61.

[16]. G. Dhinakaran, A.Rajasekharareddy, B. Kartikeyan, K. Sumanth and G.Harshavardhan. Microstructure analysis and strength properties of concrete with Nano SiO2. International Journal of ChemTech Research CODEN (USA):IJCRGG, Vol.6, No.5, 2014, 3004-3013.

[17]. Kartikeyan, B., Sumanth, K., Harshavardhan, G. and Dhinakaran, G. Microstructure analysis and Strength properties of concrete with Nano SiO2. International Journal of ChemTech Research, Vol.6, No.5, 2014, 3004-3013.

[18]. Mukharjee, Bibhuti Bhusan, Barai and Sudhirkumar V. Influence of incorporation of nano-silica and recycled aggregates on compressive strength and microstructure of concrete. Construction and Building Materials 71, 2014, 570-578.

[19]. Rathi, V.R. and Modhera, Dr. C.D.. An overview on the influence of Nano materials on properties of concrete. International Journal of Innovative Research in science, Engineering and Technology, Vol. 3, Issue 2. (2014). 